\title{
Deteksi Financial Statement Fraud Berdasarkan Perspektif Pressure dalam Fraud Triangle
}

\author{
Muhammad Yunus ${ }^{1}$ \\ Sekolah Tinggi Akuntansi dan Manajemen \\ Indonesia \\ m.yunus4994@gmail.com \\ Kharisma Yudha Saragih ${ }^{3}$ \\ Politeknik Bisnis Indonesia \\ new.yudha10@gmail.com
}

\author{
Ompon Lastiur Sianipar ${ }^{2}$ \\ Sekolah Tinggi Akuntansi dan Manajemen \\ Indonesia \\ lastiurompon27@gmail.com \\ Amelia $^{4}$ \\ Sekolah Tinggi Akuntansi dan Manajemen \\ Indonesia \\ Amelia.ak@gmail.com
}

\begin{abstract}
This study aims to determine the effect of the fraud triangle perspective illustrated by financial stability, external pressure, and financial targets on financial statement fraud on manufacturing companies listed on the Indonesia Stock Exchange in 2015-2018. This research is a type of causal associative research with a quantitative approach. The sample in this study were 49 Manufacturing Companies listed on the Indonesia Stock Exchange in 2015-2018. The type of data used in this study is secondary data. Data analysis method used in this study is Logistic Regression Analysis with the help of SPSS 25 software. The results obtained in this study indicate that external pressure has a positive and significant effect on financial statement fraud. Financial targets have a significant negative effect on financial statement fraud. While financial stability does not significantly influence financial statement fraud.
\end{abstract}

Keywords: financial stability, external pressure, dan financial target terhadap financial statement fraud.

\section{PENDAHULUAN}

Laporan keuangan perusahaan berperan memberikan informasi keuangan kepada pihakpihak yang berkepentingan terhadap perusahaan tersebut. Laporan ini bertujuan memberikan informasi mengenai posisi keuangan, kinerjakeuangan dan arus kas entitas yang bermanfaat bagi sebagian besar kalangan pengguna laporan dalam pembuatan keputusan ekonomi sebagai mana yang dinyatakan dalam Standar Akuntansi Keuangan (SAK, 2009).

Pada saat perusahaan publik menerbitkan laporan keuangannya, perusahaan tersebut pasti ingin menggambarkan kondisi perusahaannya dalam keadaan yang terbaik. Hal ini dapat menyebabkan fraud pada laporan keuangan yang akan menyesatkan investor dan pengguna laporan keuangan yang lain. Menurut Association of Certified Fraud Examiners (ACFE), fraud adalah "tindakan penipuan atau kekeliruan yang dibuat oleh seseorang atau badan yang mengetahui bahwa kekeliruan tersebut dapat mengakibatkan beberapa manfaat yang tidak baik kepada individu atau entitas atau pihak lain" (Ernst \& Young, 2009).

Dengan adanya tindakan fraud, perusahaan juga bisa mengalami kerugian besar, bukan hanya kerugian keuangan, namun juga 
kerugian penurunan nama baik perusahaan. Priantara, (2013) menyebutkan bahwa fraud dapat mengurangi reputasi perusahaan atau dapat mengurangi kemampuan perusahaan dalam mempertahankan kelangsungan bisnisnya.

Fraud merupakan sebuah risiko bisnis yang harus ditanggung oleh perusahaan akibat dari aktivitas bisnisnya, tergantung dari ukuran perusahaan tersebut. "Tidak ada satupun perusahaan/organisasi yang kebal terhadap fraud" (Purba, 2015).

Association of Certified Fraud Examiners (ACFE), dalam laporannya yang berjudul "Report to the Nations on Occupational Fraud and Abuse" melaporkan bahwa organisasi-organisasi di dunia merugi 5\% dari pendapatannya dalam tahun berjalan sebagai hasil adanya fraud. Fakta tersebut didapat dari kegiatan penelitian ACFE tehadap 114 negara-negara berbeda di seluruh dunia yang diinvestigasi dari Januari 2014 sampai Oktober 2015, yaitu United States, Sub-Saharan Africa, Asia-Pacific, Latin America \& the Carribean, Western Europe, Eastern Europe \& Western/Central Asia, Southern Asia, Canada, dan Middle East \& North Africa, yang hasilnya didapat 2.410 kasus fraud. Total kerugian yang terjadi dari kasus-kasus fraud dari penelitian
ACFE tersebut melampaui $\$ 6.3$ billion, dengan rata-rata kerugian per kasus yaitu $\$ 2.7$ million (ACFE, 2016)

Lou dan Wang (2009) mengatakan bahwa Selama dua dekade terakhir, minat dari praktisi dan akademisi di bidang kecurangan pelaporan keuangan telah tumbuh secara dramatis. Corporate fraud secara umum masuk pada salah satu dari tiga kategori berikut ini, yaitu: penyalahgunaan aset, korupsi dan kecurangan laporan keuangan. Pada dekade ini banyak skandal akuntansi yang menyebabkan pihak berspekulasi bahwa manajemen puncak telah melakukan kecurangan pada laporan keuangan. Jika kecurangan pada laporan keuangan merupakan masalah yang signifikan, profesi audit secara efektif harus mendeteksi aktivitas kecurangan tersebut sebelum berkembang menjadi skandal" (Skousen et al., 2009).

SAS No. 99, menjelaskan setidaknya ada beberapa tekanan yang mungkin mengakibatkan kecurangan pada laporan keuangan. Diantaranya yaitu financial stability, external pressure, dan financial targets. Beberapa hasil studi terdahulu menunjukkan adanya gap (celah) dalam hasil penelitian seperti yang dijelaskan oleh tabel berikut.

Tabel 1. Research Gap

\begin{tabular}{|c|c|c|c|}
\hline $\begin{array}{l}\text { Variabel } \\
\text { Dependen }\end{array}$ & $\begin{array}{c}\text { Variabel } \\
\text { Independen }\end{array}$ & $\begin{array}{c}\text { Studi } \\
\text { Terdahulu }\end{array}$ & Hasil \\
\hline \multirow{3}{*}{$\begin{array}{l}\text { Financial } \\
\text { Statement } \\
\quad \text { Fraud }\end{array}$} & \multirow{2}{*}{$\begin{array}{l}\text { Financial } \\
\text { Stability }\end{array}$} & $\begin{array}{l}\text { Maghfiroh, et al., (2015); Nugraheni dan Triatmoko } \\
\text { (2017); Rachmania (2017); Wahyuni dan } \\
\text { Budiwitjaksono (2017); Aprillia, et al., (2015) dan } \\
\text { Zaki (2017). }\end{array}$ & $\begin{array}{c}\text { Tidak Berpengaruh } \\
\text { Signifikan }\end{array}$ \\
\hline & & $\begin{array}{l}\text { Annisya, et al., (2016); } \\
\text { Tiffani dan Marfuah (2017); Prasmaulida (2016); } \\
\text { dan Darmawan dan Oktoria (2017). }\end{array}$ & $\begin{array}{l}\text { Berpengaruh } \\
\text { Signifikan }\end{array}$ \\
\hline & $\begin{array}{l}\text { External } \\
\text { Pressure }\end{array}$ & $\begin{array}{l}\text { Wahyuni dan Budiwitjaksono (2017); Amara, et al., } \\
\text { (2013) dan Annisya, } \\
\text { et al., (2016); }\end{array}$ & $\begin{array}{l}\text { Tidak Berpengaruh } \\
\text { Signifikan }\end{array}$ \\
\hline
\end{tabular}




\begin{tabular}{|c|c|c|c|}
\hline $\begin{array}{l}\text { Variabel } \\
\text { Dependen }\end{array}$ & $\begin{array}{l}\text { Variabel } \\
\text { Independen }\end{array}$ & $\begin{array}{c}\text { Studi } \\
\text { Terdahulu }\end{array}$ & Hasil \\
\hline & & $\begin{array}{l}\text { Tiffani dan Marfuah (2017); Maghfiroh, et al., } \\
\text { (2015); Rachmania (2017); Nugraheni dan } \\
\text { Triatmoko (2017); Aghghaleh et al., (2014); Dalnial, } \\
\text { et al., (2014); dan Zaki (2017). }\end{array}$ & $\begin{array}{l}\text { Berpengaruh } \\
\text { Signifikan }\end{array}$ \\
\hline & \multirow[b]{2}{*}{$\begin{array}{l}\text { Financial } \\
\text { Target }\end{array}$} & $\begin{array}{l}\text { Wahyuni dan Budiwitjaksono (2017); } \\
\text { Zaki (2017); dan Aprillia, et al., (2015). }\end{array}$ & $\begin{array}{l}\text { Tidak Berpengaruh } \\
\text { Signifikan }\end{array}$ \\
\hline & & $\begin{array}{l}\text { Annisya, et al., (2016); } \\
\text { Nugraheni dan Triatmoko (2017); } \\
\text { Annisa (2017); Amara, et al., (2013); dan Darmawan } \\
\text { dan Oktoria (2017). }\end{array}$ & $\begin{array}{l}\text { Berpengaruh } \\
\text { Signifikan }\end{array}$ \\
\hline
\end{tabular}

Sumber: Review Studi Terdahulu

Dengan adanya research gap dari studi terdahulu di atas, maka perlu dilakukan penelitian lanjutan mengenai pengaruh financial stability, external pressure, dan financial target terhadap financial statement fraud pada perusahaan yang terdaftar di Bursa Efek Indonesia. Penelitian ini difokuskan pada industri manufaktur yang merupakan industri yang paling mendominasi perusahaanperusahaan yang terdaftar di Bursa Efek Indonesia. Dimana lebih dari $40 \%$ perusahaan yang terdaftar di BEI adalah perusahaan manufaktur, dengan demikian, industri ini menjadi salah satu pelaku terpenting dalam mendukung perekonomian di Indonesia.

\subsection{Rumusan Masalah}

Berdasarkan uraian latar belakang diatas, maka perumusan masalah dalam penelitian ini adalah sebagai berikut:

a. Apakah financial stability berpengaruh terhadap financial statement fraud pada perusahaan manufaktur yang terdaftar di Bursa Efek Indonesia?

b. Apakah external pressure berpengaruh terhadap financial statement fraud pada perusahaan manufaktur yang terdaftar di Bursa Efek Indonesia?

c. Apakah financial target berpengaruh terhadap financial statement fraud pada perusahaan manufaktur yang terdaftar di Bursa Efek Indonesia?

\subsection{Pengembangan Hipotesis}

a. Pengaruh financial stability terhadap financial statement fraud.

SAS No. 99 menjelasakna bahwa manajer biasanya akan menghadapi tekanan untuk melakukan kecurangan laporan keuangan ketika stabilitas keuangan (financial stability) terancam oleh keadaan ekonomi, industri, dan situasi entitas yang beroperasi. Financial stability merupakan keadaan yang menggambarkan kondisi ketidakstabilan keuangan perusahaan (Skousen, et al., 2009). Sehingga financial stability akan berdampak pada kegiatan financial statement fraud.

Teori tersebut didukung oleh hasil studi terdahulu yang dilakukan oleh Annisya, et al., (2016); Tiffani dan Marfuah (2017); Prasmaulida (2016); dan Darmawan dan Oktoria (2017) menunjukkan bahwa financial stability memiliki pengaruh yang signifikan terhadap financial statement fraud.

\section{H1: Financial stability berpengaruh} terhadap financial statement fraud.

\section{b. Pengaruh external pressure terhadap financial statement fraud.}


External pressure merupakan tekanan yang berlebihan bagi manajemen untuk memenuhi persyaratan atau harapan dari pihak ketiga. SAS No. 99 menjelaskana saat tekanan yang diterima oleh pihak manajemen terasa berlebihan dari pihak eksternal, maka terdapat risiko kecurangan terhadap laporan keuangan. Hal ini didukung oleh pendapat Skousen, et al., (2009) yang menyatakan bahwa salah satu tekanan yang seringkali dialami manajemen perusahaan adalah kebutuhan untuk mendapatkan tambahan utang atau sumber pembiayaan eksternal. Dan tekanan ini akan berujung pada tindakan financial statement fraud.

Teori tersebut didukung oleh hasil studi terdahulu yang dilakukan oleh Tiffani dan Marfuah (2017); Maghfiroh, et al., (2015); Rachmania (2017); Nugraheni dan Triatmoko (2017); Aghghaleh et al., (2014); Dalnial, et al., (2014); dan Zaki (2017) yang menunjukkan bahwa external pressure memiliki pengaruh yang signifikan terhadap financial statement fraud.

\section{H2: External pressure berpengaruh terhadap financial statement fraud.}

\section{c. Pengaruh financial target terhadap financial statement fraud.}

SAS No. 99 menjelaskan bahwa financial target adalah risiko adanya tekanan berlebihan pada manajemen untuk mencapai target keuangan yang dipatok oleh direksi atau manajemen, termasuk tujuan-tujuan penerimaan insentif dari penjualan maupun keuntungan.

Dalam penelitian ini, financial target diukur berdasarkan ROA. Skousen, et al., (2009) mengatakan bahwa return on asset (ROA) ini sering digunakan dalam menilai performa manajer dan dalam menentukan bonus, kenaikan upah, dan lain-lain. Dengan adanya financial target yang terlalu tinggi maka akan memaksa pihak manajemen untuk melakukan tindakan financial statement fraud.

Teori tersebut didukung oleh hasil studi terdahulu yang dilakukan oleh Annisya, et al., (2016); Nugraheni dan Triatmoko (2017); Annisa (2017); Amara, et al., (2013); dan Darmawan dan Oktoria (2017) yang menunjukkan bahwa financial target memiliki pengaruh yang signifikan terhadap financial statement fraud.

\section{METODE PENELITIAN}

Penelitian ini merupakan jenis penelitian asosiatif kausal dengan pendekatan kuantitatif. Teknik penentuan sampel dalam penelitian ini menggunakan teknik purposive sampling. Berdasarkan kriteria yang ditentukan, maka diperoleh sampel dalam penelitian ini sebanyak 49 perusahaan manufaktur yang terdaftar di Bursa Efek Indonesia. Amatan dalam penelitian ini dilaksanakan sepanjang periode 2015 sampai 2018. Sehingga jumlah observasi dalam penelitian ini berjumlah 196 data.

Jenis data yang digunakan dalam penelitian ini adalah data sekunder. Sedangkan metode analisis data yang digunakan dalam penelitian ini adalah Analisis Regresi Logistik dengan bantuan software SPSS 25 karena variabel dependen yang digunakan adalah variabel dummy.

\section{HASIL DAN PEMBAHASAN}

\subsection{Analisis Logistic Regression}

Variabel terikat dalam penelitian ini merupakan variabel dummy yaitu financial statement fraud, maka metode analisis yang digunakan untuk menguji hipotesis dalam penelitian ini adalah regresi logistik (logistic regression).

Dalam penggunaannya, analisis regresi logistik tidak memerlukan distribusi yang normal pada variabel bebasnya (variabel independen). Di samping itu, teknik analisis ini juga tidak memerlukan pengujian normalitas, 
pengujian heteroskedastisitas dan pengujian asumsi klasik lainnya pada variabel bebasnya (Ghozali, 2013).

Tabel 2. Data Penelitian

Case Processing Summary

\begin{tabular}{llr|r} 
Unweighted Cases & $\mathrm{N}$ & Percent \\
\hline $\begin{array}{l}\text { Selected } \\
\text { Cases }\end{array}$ & Included in & 196 & 100.0 \\
& Analysis & & \\
\cline { 2 - 4 } & Missing Cases & 0 & .0 \\
\cline { 2 - 4 } & Total & 196 & 100.0 \\
\hline Unselected Cases & 0 & .0 \\
\hline Total & 196 & 100.0 \\
\hline
\end{tabular}

a. If weight is in effect, see classification table for the total number of cases.

Berdasarkan tabel Case Processing Summary di atas dapat dilihat bahwa tidak ada missing cases yang terdapat dalam model penelitian ini sehingga jumlah observasi yang digunakan dalam penelitian ini adalah sebanyak 196 sampel (49 perusahaan $\mathrm{x} 4$ tahun penelitian).

Tabel 3. Pengkodean Variabel Dependen Dependent Variable Encoding

\begin{tabular}{lr} 
Original Value & Internal Value \\
\hline Tidak Adanya Financial & 0 \\
Statement Fraud & \\
\hline $\begin{array}{l}\text { Adanya Financial Statement } \\
\text { Fraud }\end{array}$ & 1 \\
\hline
\end{tabular}

Tabel diatas menunjukkan kode dari variabel dependen. Terdapat 2 kategori dalam variabel dependen yaitu kategori "Tidak Adanya Financial Statement Fraud" dengan

Tabel 4. Overall Model Fit

Block 0: Beginning Block Iteration History ${ }^{\mathrm{a}, \mathrm{b}, \mathrm{c}}$

\begin{tabular}{lrr|r} 
Iteration & -2 Log likelihood & \multicolumn{1}{c}{$\begin{array}{c}\text { Coefficients } \\
\text { Constant }\end{array}$} \\
\hline Step 0 & 1 & 271.203 & -.102 \\
\cline { 2 - 4 } & 2 & 271.203 & -.102 \\
\hline
\end{tabular}

a. Constant is included in the model.

b. Initial -2 Log Likelihood: 271.203 


\section{c. Estimation terminated at iteration number 2 because parameter estimates changed by less than .001 .}

\section{Block 1: Method = Enter}

\begin{tabular}{|c|c|c|c|c|c|c|}
\hline \multicolumn{7}{|c|}{ tory,b. } \\
\hline \multirow[b]{2}{*}{ Iteration } & & & \multicolumn{4}{|c|}{ Coefficients } \\
\hline & & $\begin{array}{l}-2 \text { Log } \\
\text { likelihood }\end{array}$ & Constant & $\begin{array}{l}\text { Financial } \\
\text { Stability }\end{array}$ & $\begin{array}{l}\text { External } \\
\text { Pressure }\end{array}$ & $\begin{array}{c}\text { Financial } \\
\text { Targets }\end{array}$ \\
\hline \multirow[t]{5}{*}{ Step 1} & 1 & 225.747 & -.335 & .148 & 1.170 & -7.665 \\
\hline & 2 & 217.783 & -.748 & .179 & 2.323 & -10.609 \\
\hline & 3 & 216.981 & -.991 & .172 & 2.927 & -11.366 \\
\hline & 4 & 216.976 & -1.008 & .171 & 2.971 & -11.467 \\
\hline & 5 & 216.976 & -1.008 & .171 & 2.971 & -11.468 \\
\hline \multicolumn{3}{|c|}{$\begin{array}{l}\text { a. Method: Enter } \\
\text { b. Constant is included in the model. } \\
\text { c. Initial -2 Log Likelihood: } 271.203\end{array}$} & el. & ans & 4. & ss \\
\hline
\end{tabular}

Tabel Iteration History pada block 0 atau saat variabel independen tidak dimasukkan dalam model: $\mathrm{N}=196$ mendapatkan Nilai -2 Log Likelihood sebesar 271.203. Sedangkan pada tabel Iteration History pada block 1 atau saat variabel independen dimasukkan kedalam model: N=196 mendapatkan Nilai -2 Log Likelihood: 216.976. Nilai -2 LL awal dikurangi nilai -2 LL selanjutnya yaitu $271.203-216.976=54.227$.

Pengurangan nilai antara $-2 \quad \log$ likelihood awal dengan nilai -2 log likelihood pada langkah berikutnya memiliki selisih sebesar 54.227. Ini menunjukkan bahwa variabel yang dihipotesiskan sudah fit dengan data.

\subsection{Uji Koefisien Determinasi $\left(\mathbf{R}^{2}\right)$}

Model summary dalam regresi logistik sama dengan pengujian $\mathrm{R}^{2}$ pada persamaan regresi linear. Tujuan dari model summary adalah untuk mengetahui seberapa besar kombinasi variabel independen mempu menjelaskan variasi variabel dependen.
Tabel 5. Hasil Uji Koefisien Determinasi $\left(\mathrm{R}^{2}\right)$ Model Summary

\begin{tabular}{lr|r|r} 
Step & $\begin{array}{c}-2 \text { Log } \\
\text { likelihood }\end{array}$ & $\begin{array}{c}\text { Cox \& Snell } \\
\text { R Square }\end{array}$ & $\begin{array}{c}\text { Nagelkerke R } \\
\text { Square }\end{array}$ \\
\hline 1 & $216.976^{a}$ & .242 & .323
\end{tabular}

a. Estimation terminated at iteration number 5 because parameter estimates changed by less than .001 .

Nilai Nagelkerke $R$ Square sebesar 0.323 menunjukkan bahwa kemampuan variabel independen dalam menjelaskan variabel dependen adalah sebesar 0.323 atau $32.3 \% \%$ dan selebihnya $67.7 \%$ dijelaskan oleh variabel lain yang tidak dimasukkan ke dalam model penelitian ini.

\subsection{Uji Kelayakan Model Regresi}

Uji kelayakan model regresi (goodness of fit test) dapat dilakukan dengan memperhatikan output dari Hosmer and Lemeshow's. Jika nilai statistik Hosmer and Lemeshow sama dengan atau kurang dari 0.05, maka hipotesis nol (H0) ditolak dan hal tersebut berarti terdapat perbedaan siginifikan antara model dengan nilai observasinya sehingga Goodness of Fit Test Model tidak baik karena 
model tidak dapat memprediksi nilai observasinya. Sebaliknya jika nilai statistik Hosmer and Lemeshow lebih dari 0.05, maka hipotesis nol (H0) tidak dapat ditolak, yang berarti model mampu memprediksi nilai observasinya.

Tabel 6. Hasil Uji Kelayakan Model Regresi Hosmer and Lemeshow Test

\begin{tabular}{lrrrrr} 
Step & Chi-square & df & & \multicolumn{1}{l}{ Sig. } \\
\hline 1 & 11.341 & & 8 & .183 \\
\hline
\end{tabular}

Tabel hasil pengujian kelayakan model regresi yang ditunjukkan pada tabel Hosmer and Lemeshow di atas. Pada tabel tersebut menunjukkan bahwa nilai signifikan dari output Hosmer and Lemeshow Test adalah 0.208. Nilai signifikan pada tabel Hosmer and
Lemeshow tersebut diketahui lebih besar dari probabilitas $5 \%$ yaitu 0.05 . Sehingga dengan hasil tersebut maka dapat disimpulkan bahwa model yang digunakan dalam penelitian ini telah mampu memprediksi nilai observasinya.

\subsection{Uji Wald}

Pada regresi logistik digunakan uji wald, dimana berfungsi untuk menguji signifikansi konstanta dari setiap variabel independen yang masuk ke dalam model. Oleh karena itu, jika dalam uji wald memperlihatkan angka signifikansi yang lebih kecil dari 0.05, maka koefisien regresi adalah signifikan pada tingkat kepercayaan 5\%. Penentuan diterima atau tidaknya $\mathrm{H} 0$ didasarkan pada tingkat signifikansi $\alpha(5 \%)$ dengan kriteria sebagai berikut.

Tabel 7. Hasil Uji Wald

\begin{tabular}{|c|c|c|c|c|c|c|c|c|c|}
\hline \multicolumn{10}{|c|}{ Variables in the Equation } \\
\hline & & \multirow[b]{2}{*}{ B } & \multirow[b]{2}{*}{ S.E. } & \multirow[b]{2}{*}{ Wald } & \multirow[b]{2}{*}{$d f$} & \multirow[b]{2}{*}{ Sig. } & \multirow[b]{2}{*}{$\operatorname{Exp}(B)$} & \multicolumn{2}{|c|}{ 95\% C.I.for EXP(B) } \\
\hline & & & & & & & & Lower & Upper \\
\hline \multirow[t]{4}{*}{ Step $1^{a}$} & Financial Stability & .171 & .404 & .178 & 1 & .673 & 1.186 & .537 & 2.618 \\
\hline & External Pressure & 2.971 & .869 & 11.699 & 1 & .001 & 19.520 & 3.556 & 107.142 \\
\hline & Financial Targets & -11.468 & 3.402 & 11.367 & 1 & .001 & .000 & .000 & .008 \\
\hline & Constant & -1.008 & .468 & 4.643 & 1 & .031 & .365 & & \\
\hline
\end{tabular}

a. Variable(s) entered on step 1: Financial Stability, External Pressure, Financial Targets.

Persamaan di atas menunjukkan bahwa koefisien dari variabel financial stability dan external pressure bernilai positif. Sedangkan koefisien regresi dari variabel financial target bernilai negatif.

Pada saat variabel independen telah dimasukkan ke dalam model penelitian (block number $=1)$. Uji statistik wald menghasilkan:

a. Variabel financial stability memiliki nilai signifikan 0.673 pada signifikansi $5 \%$. Karena nilai sig. $0.673>0.05$, maka $\mathrm{H}_{\mathrm{a}}$ ditolak atau hipotesis yang menyatakan financial stability berpengaruh terhadap financial statement fraud ditolak.

b. Variabel external pressure memiliki nilai signifikan 0.001, karena nilai sig. $0.001<$ 0.05 , maka $\mathrm{H}_{\mathrm{a}}$ diterima atau hipotesis yang menyatakan bahwa external pressure berpengaruh terhadap financial statement fraud diterima.

c. Variabel financial target memiliki nilai signifikan 0.001, karena nilai sig. $0.001<$ 0.05, maka $\mathrm{H}_{\mathrm{a}}$ diterima sedangkan $\mathrm{H}_{0}$ ditolak. Yang berarti hipotesis yang menyatakan financial target berpengaruh 
signifikan terhadap financial statement fraud diterima.

\subsection{Omnibus Tests of Model Coefficients}

Perlu diingat jika pada analisis regresi linear berganda untuk menguji signifikansi simultan menggunakan uji $\mathrm{F}$, sedangkan pada regresi logistik menggunakan nilai Chi-Square dari selisih antara -2 Log likelihood sebelum variabel independen masuk model dan -2 Log likelihood setelah variabel independen masuk model. Pengujian ini disebut juga dengan pengujian Maximum likelihood.

Tabel 8. Hasil Omnibus Test

\section{Omnibus Tests of Model Coefficients}

\begin{tabular}{llr|r|r} 
& & Chi-square & df & \multicolumn{1}{c}{ Sig. } \\
\hline Step 1 & Step & 54.227 & 3 & .000 \\
\cline { 2 - 5 } & Block & 54.227 & 3 & .000 \\
\cline { 2 - 5 } & Model & 54.227 & 3 & .000 \\
\hline
\end{tabular}

Pada tabel Omnibus Tests of Model Coefficients dapat dilihat nilai Chi-square, $d f$ dan signifikan Omnibus. Nilai signifikan sebesar 0.000 dimana $0.000<$ Alpha 0.05 atau nilai Chi-Square Hitung (selisih -2LL awal dan -2LL selanjutnya) sebesar $54.227>$ Chi-Square tabel yaitu 7.810 pada $d f 3$.

Sehingga dapat disimpulkan bahwa secara simultan financial stability, external pressure dan financial target berpengaruh signifikan terhadap financial statement fraud.

\subsection{Pembahasan}

\section{a. Pengaruh financial stability terhadap financial statement fraud.}

Hasil pengolahan data dalam penelitian ini menunjukkan bahwa hubungan antara financial stability dengan financial statement fraud adalah positif, hanya saja hubungan ini tidak signifikan. Dengan hasil tersebut maka $\mathrm{H}_{1}$ atau hipotesis yang menyatakan financial stability berpengaruh terhadap financial statement fraud ditolak.
Secara teoritis, SAS No. 99 menjelasakna bahwa manajer biasanya akan menghadapi tekanan untuk melakukan kecurangan laporan keuangan ketika stabilitas keuangan (financial stability) terancam oleh keadaan ekonomi, industri, dan situasi entitas yang beroperasi. Financial stability merupakan keadaan yang menggambarkan kondisi ketidakstabilan keuangan perusahaan (Skousen, et al., 2009). Sehingga financial stability akan berdampak pada kegiatan financial statement fraud.

Hasil penelitian ini sejalan dengan penelitian yang dilakukan oleh Nur Maghfiroh, dkk., (2015) yang dalam penelitiannya menyatakan bahwa financial stability tidak berpengaruh signifikan terhadap financial statement fraud. Hasil tersebut juga dikuatkan oleh hasil penelitian yang dilakukan oleh Nugraheni dan Triatmoko (2017); Rachmania (2017); Wahyuni dan Budiwitjaksono (2017); dan Annisya, dkk., (2016) yang juga menyatakan bahwa financial stability tidak memiliki pengaruh yang signifikan terhadap financial statement fraud.

b. Pengaruh external pressure terhadap financial statement fraud.

Hasil pengolahan data dalam penelitian ini menunjukkan bahwa external pressure memiliki pengaruh yang positif dan signifikan terhadap financial statement fraud. Dengan hasil tersebut maka $\mathrm{H}_{2}$ atau hipotesis yang menyatakan external pressure berpengaruh terhadap financial statement fraud diterima.

Seara teoritis, external pressure merupakan tekanan yang berlebihan bagi manajemen untuk memenuhi persyaratan atau harapan dari pihak ketiga. SAS No. 99 menjelaskana saat tekanan yang diterima oleh pihak manajemen terasa berlebihan dari pihak eksternal, maka terdapat risiko 
kecurangan terhadap laporan keuangan. Hal ini didukung oleh pendapat Skousen, et al., (2009) yang menyatakan bahwa salah satu tekanan yang seringkali dialami manajemen perusahaan adalah kebutuhan untuk mendapatkan tambahan utang atau sumber pembiayaan eksternal. Dan tekanan ini akan berujung pada tindakan financial statement fraud

Hasil dalam penleitian ini didukung oleh hasil studi terdahulu yang dilakukan oleh Tiffani dan Marfuah (2017); Maghfiroh, et al., (2015); Rachmania (2017); Nugraheni dan Triatmoko (2017); Aghghaleh et al., (2014); Dalnial, et al., (2014); dan Zaki (2017) yang menunjukkan bahwa external pressure memiliki pengaruh yang signifikan terhadap financial statement fraud.

\section{c. Pengaruh financial target terhadap} financial statement fraud.

Hasil pengolahan data dalam penelitian ini menunjukkan bahwa financial target memiliki pengaruh yang negatif dan signifikan terhadap financial statement fraud. Dengan hasil tersebut maka $\mathrm{H}_{3}$ atau hipotesis yang menyatakan financial target berpengaruh terhadap financial statement fraud diterima.

Secara teoritis, SAS No. 99 menjelaskan bahwa financial target adalah risiko adanya tekanan berlebihan pada manajemen untuk mencapai target keuangan yang dipatok oleh direksi atau manajemen, termasuk tujuan-tujuan penerimaan insentif dari penjualan maupun keuntungan. Dalam penelitian ini, financial target diukur berdasarkan ROA. Skousen, et al., (2009) mengatakan bahwa return on asset (ROA) ini sering digunakan dalam menilai performa manajer dan dalam menentukan bonus, kenaikan upah, dan lain-lain. Dengan adanya financial target yang terlalu tinggi maka akan memaksa pihak manajemen untuk melakukan tindakan financial statement fraud.

Hasil penelitian ini didukung oleh hasil studi terdahulu yang dilakukan oleh Annisya, et al., (2016); Nugraheni dan Triatmoko (2017); Annisa (2017); Amara, et al., (2013); dan Darmawan dan Oktoria (2017) yang menunjukkan bahwa financial target memiliki pengaruh yang signifikan terhadap financial statement fraud.

\section{KESIMPULAN}

Berdasarkan hasil analisa dan pengolahan data pada penelitian ini, maka dapat dibuat beberapa kesimpulan sebagai berikut:

1. Financial stability tidak berpengaruh signifikan terhadap financial statement fraud pada perusahaan manufaktur yang terdaftar di Bursa Efek Indonesia.

2. External pressure berpengaruh positif dan signifikan terhadap financial statement fraud pada perusahaan manufaktur yang terdaftar di Bursa Efek Indonesia.

3. Financial target berpengaruh negatif dan signifikan terhadap financial statement fraud pada perusahaan manufaktur yang terdaftar di Bursa Efek Indonesia.

\section{REFERENSI}

Aghghaleh, S. F., Iskandar, T. M., dan Mohamed, Z. M. (2014). Fraud Risk Factors of Fraud Triangle and the Likelihood of Fraud Occurrence : Evidence from Malaysia. Information Management and Business Review, 6 (1), 1-7.

AICPA. 2002. Consideration of fraud in a financial statement audit. Statement on Auditing Standard No. 99. AICPA. New York.

Amara, I., Ben, A. A., dan Jarboui, A. (2013). Functions and Reliability of International Financial Reporting Systems of Rural Smes in Kwazulu 
Natal: Knowledge and Understanding of Financial Management. International Journal of Academic Research in Accounting Finance and Management Sciences, 3 (3), 125132.

Annisya, M., Lindrianasari dan Asmaranti, Y. (2016). Pendeteksian Kecurangan Laporan Keuangan Menggunakan Fraud Diamond. Jurnal Bisnis dan Ekonomi. Fakultas Ekonomi dan Bisnis, Universitas Lampung.

Aprillia., Cicilia, O., dan Sergius, R. P. (2015). The Effectiveness of Fraud Triangle on Detecting Fraudulent Financial Statement: Using Beneish Model and the Case of Special Companies. Jurnal Riset Akuntansi Dan Keuangan. 3 (3), 786-800.

Association of Certified Fraud Examiners. (2016). Report to the Nations on Occupational Fraud and Abuse. Association of Certified Fraud Examiners.

Dalnial, H., Kamaluddin, A., Sanusi, Z. M., dan Khairuddin, K. S. (2014). Accountability in Financial Reporting: Detecting Fraudulent Firms. Procedia - Social and Behavioral Sciences. 145, 61-69.

Darmawan, A., dan Oktoria, S. (2017). The Impact of Auditor Quality, Financial Stability, and Financial Target for Fraudulent Financial Statement, Journal of Applied Accounting and Taxation. 2 (1), 9-14.

Ernst\&Young. (2009). Detecting Fiancial Statement Fraud: What Every Manger Needs to know.

Ghozali, I. (2013). Aplikasi Analisis Multivariate Dengan Program IBM SPSS 21 Update PLS Regresi.
Semarang: Badan Penerbit Universitas Diponegoro.

Maghfiroh, N., Ardiyan, K., dan Syafnita (2015). Analisis Pengaruh Financial Stability, Personal Financial Need, External Pressure dan Ineffective Monitorng Pada Financial Statement Fraud dalam Perspektif Fraud Diamond. Jurnal Ekonomi dan Bisnis. Fakultas Ekonomi Universitas Pekalongan.

Manurung, D. T. H., dan Hardika, A. L. (2015). Analysis of Factors That Influence Financial Statement Fraud In The Perspective Fraud Diamond: Empirical Study on Banking Companies Listed on The Indonesia Stock Exchange Year 2012 to 2014. International Conference on Accounting Studies (ICAS).

Nugraheni, N. K., dan Triatmoko, H. (2017). Analisis Faktor-Faktor Yang Mempengaruhi Terjadinya Financial Statement Fraud: Perspektif Diamond Fraud Theory (Studi Pada Perusahaan Perbankan Yang Terdaftar Di Bursa Efek Indonesia Periode 2014-2016). Jurnal Akuntansi dan Auditing. Fakultas Ekonomi dan Bisnis Universitas Sebelas Maret.

Priantara, D. (2013). Fraud Auditing \& Investigation. Mitra Wacana Media. Jakarta.

Purba, B. P. (2015). Fraud dan Korupsi: Pencegahan, Pendeteksian, dan Pemberantasannya. Jakarta Timur: Lestari Kiranatama.

Rachmania, A. (2017). Analisis Pengaruh Fraud Triangle Terhadap Kecurangan Laporan Keuangan Pada Perusahaan Makanan dan Minuman Yang Terdaftar di Bursa Efek Indonesia 
Periode 2013-2015. Fakultas

Ekonomi dan Bisnis Universitas

Pakuan

Ross, A. S. (1973). The Economic Theory of Agency: The Pricipals Problem.

Skousen, C. J., Smith, K. R. dan Wright, C. J. (2009) Detecting and Predicting Financial Statement Fraud : The Effectiveness of The Fraud Triangle and $S A S$

Tiffani, L. dan Marfuah (2017). Deteksi Financial Statement Fraud dengan Analisis Fraud Triangle Pada Perusahaan Manufaktur yang Terdaftar di Bursa Efek Indonesia. Jurnal Akuntansi dan Auditing Indonesia.

Wahyuni dan Budiwitjaksono, B. S. (2017). Fruad Triangle sebagai Pendeteksi Kecurangan Laporan Keuangan. Jurnal Akuntansi. Fakultas Ekonomi dan Bisnis UPN Veteran, Jawa Timur.

Zaki, N. M. (2017). The Appropriateness of Fraud Triangle and Diamond Models in Assesing The Likelihood of Fraudulent Financial Statements- An Empirical Study on Firms Listed in The Egyptian Stock Exchange. International Journal of Social Science and Economic Research. ISSN:, 2 (2), 2403-2433. 